\title{
Bioactive Components Retention in Processed Indian Gooseberry Products
}

\author{
Vinita Puranik, Vandana Mishra*, Neelam Yadav and G.K.Rai \\ Centre of Food Technology, University of Allahabad, Allahabad, Uttar Pradesh, India
}

\begin{abstract}
Indian gooseberry is a rich source of ascorbic acid and various other bioactive components when compared to other citrus fruits. Present work was carried out for the development and evaluation of bioactive components in processed products from Indian gooseberry. Indian gooseberry candy, bar and toffee were developed by standard procedures. Ascorbic acid content, polyphenolics and DPPH\% scavenging activity was estimated in these processed products and the results were compared to amla to see the degradation of bioactive components during processing. Sensory evaluation was also carried out for the samples. Maximum amount of ascorbic acid content was found in Indian gooseberry candy with decreasing order in bar and minimum in Indian gooseberry toffee. Polyphenolics were determined in terms of gallic acid equivalent while antioxidant activity was evaluated as DPPH \% scavenging activity. It was found that amla can be utilized for the development of various value added products which retains bioactive components even after processing.
\end{abstract}

Keywords: Indian gooseberry; Bioactives; Processing; Ascorbic acid; Polyphenols

\section{Introduction}

Amla, also known as Indian gooseberry (Emblica officinalis), is one of the useful fruit [1]. It is consumed as a fresh fruit or in the form of food products like preserves. The amla is regarded as main ingredient in many ayurvedic preparations like chyvanprash and is regarded as rejuvenating herb $[2,3]$. Amla is a rich source of vitamin $C$, which rank second next to Barbados cherry which has maximum vitamin C [2,4-8]. It is found to posses anti-aging, expectorant, purgative, antibacterial, antioxidant, hypoglycemic activity [8-10]. Many different products have been reported from amla like ready-to-serve beverage [8,11], candy, jam, powder [12], Amla bar [13]. Amla berries can be used as a valuable ingredient for the production of an herbal fermented beverage. The Indian gooseberry is native to India and also grows in tropical and subtropical regions [8]. In addition of being an important medicinal herbs, it has potent antioxidant, several active tannoid principles (Emblicannin A, Emblicannin B, Punigluconin and Pedunculagin) have been identified which to account for its health benefits like antioxidant activity, antiaging property [14-16]. The Amla fruit, because of its high acidity and astringent taste, is not prefered for direct consumption; hence it is consumed mainly after processing, as processed product $[8,13]$. Present study was done to prepare preserved product utilizing bioactive rich underutilized fruit amla.

\section{Material and Methods}

\section{Raw material}

Present study was carried out in 2009-2011 at Centre of Food Technology, University of Allahabad, Allahabad, U.P, India. Amla chakaiya varieties were procured from the local market. Other raw material like skim milk powder, sugar, fat, liquid glucose, glucose and skim milk powder were also procured from the local market. The procured amla were stored at room temperature in jute bag until they were used for the product development.

Selection of the method of preservation: Food Preservation has an important role in the conservation and better utilization of fruits and vegetables. In order to avoid glut and utilize the surplus during the season, it is necessary to employ methods to extend storage life, for better distribution and to preserve them for utilization in the off-season both in large scale and home scale. Jam is more or less a concentrated fruit processed product which has fairly thick consistency and body. It is also rich in flavour, because ripened fruits which have developed full flavour are used in its preparation. A great advantage in its preparation is that it can be prepared in a single operation. The amla fruit, because of its high acidity and astringent taste, is not palatable for direct consumption; hence it is consumed mainly in processed form present study was done to prepare preserved product utilizing bioactive rich underutilized fruit amla.

Pre-preparation of the amla: Sorting and grading is essential to get suitable quality of fruit which was done by hand. The fruits were first washed to remove the dirt. Grading of fruit was done based on soundness, firmness, cleanliness, size, maturity, weight, color, shape and freedom from foreign matters, insect damage and mechanical injury. From the graded amla the pulp was extracted manually. It was homogenized in a mixer to obtain fine pulp.

Preparation of processed product from amla: The procedure for the preparation of amla toffee was given in figure 1 , amla bar in figure 2 and amla candy in figure 3.

\section{Total soluble solids}

Total soluble solids (TSS) of fruit juice was analyzed by Digital Refractometer (Rudolph, USA). The fruit pulp was extracted and

*Corresponding author: Vandana Mishra, Centre of Food Technology, University of Allahabad, Allahabad, Uttar Pradesh, India, E-mail: mvandana22@gmail.com

Received September 15, 2012; Accepted November 12, 2012; Published November 21, 2012

Citation: Puranik V, Mishra V, Yadav N, Rai GK (2012) Bioactive Components Retention in Processed Indian Gooseberry Products. J Food Process Technol 3 : 194. doi:10.4172/2157-7110.1000194

Copyright: @ 2012 Puranik V, et al. This is an open-access article distributed under the terms of the Creative Commons Attribution License, which permits unrestricted use, distribution, and reproduction in any medium, provided the original author and source are credited. 
filtered through muslin cloth. A drop of filtrate was placed on a refractometer prism and the total soluble solids were recorded as ${ }^{\circ}$ Brix.

\section{Moisture, crude, fat, protein and titrable acidity}

Moisture, Protein and Crude fat content of the samples were determined as per [17] procedures and total ash as per [18]. Titrable acidity was calculated by titration method given in [19].

\section{Ascorbic acid}

Sample solution equivalent to $0.2 \mathrm{mg}$ ascorbic acid/ $\mathrm{ml}$ was prepared in water containing $3 \%(\mathrm{w} / \mathrm{v})$ metaphosphoric acid. It was titrated against standard 2, 6 dichlorophenol indophenol (2,6 DCIP) solution of $0.5 \mathrm{mg} / \mathrm{ml}$ concentration until the pink color developed completely. The operation was repeated with a blank [20].

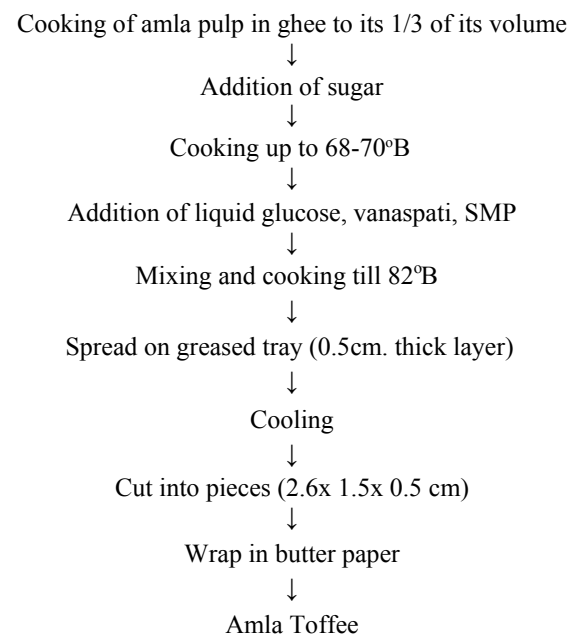

Figure 1: Flow diagram for the preparation of Amla Toffee.

\section{(Syrup preparation) \\ Sugar + water $\downarrow$ \\ Boil to remove scum}

$$
\downarrow
$$

Syrup of $75^{\circ} \mathrm{B}$ cooking of amla pulp in ghee to its $1 / 3$ of its volume (for 25 mins)

Addition of $3 / 4^{\text {th }}$ part of syrup and pectin $\downarrow$

Addition of glucose powder

Cooked for $2 \mathrm{~min}$ and add SMP in paste form

(With $1 / 4^{\text {th }}$ of syrup)

$\downarrow$

Cook till it leaves the corners of the pan $\downarrow$

Spread on greased tray $(0.5 \mathrm{~cm}$. thick layer $)$

$\downarrow$

Cooling it at room temperature for 30 mins $\downarrow$

Wrap in butter paper $\downarrow$

Packing in PET jars

Figure 2: Flow diagram for the preparation of Amla Bar.

\section{Amla fruit washing with water $\downarrow$ \\ Water blanching and slicing $\downarrow$}

Syrup treatment (osmosis treatment increased syrup penetration) $\downarrow$

Preparation of syrup with sugar upto $48^{\circ}$ Brix $\downarrow$

Steeping of amla in sugar syrup for 24 hours and washing

Repeat the process with syrup of $58^{\circ} \mathrm{B}$ for next 24 hours and washing $\downarrow$

Repeat the process with syrup of $72^{\circ} \mathrm{B}$ for next 24 hours and washing $\downarrow$

Drying in hot air oven at $55^{\circ} \mathrm{C}$ for 2 hours

$\stackrel{\downarrow}{\downarrow}$

$\downarrow$

Filling in PET jars

Figure 3: Flow diagram for the preparation of Amla candy.

\section{Total phenolic content}

Total polyphenols were estimated as per procedure described by [21] where, $250 \mathrm{mg}$ sample was taken in $10 \mathrm{ml}$ of acetone and water $(70: 30 \mathrm{v} / \mathrm{v})$ solution in a graduated test tube and heated on water bath at $70^{\circ} \mathrm{C}$ for $10 \mathrm{~min}$. The sample was brought to room temperature, centrifuged at $3500 \mathrm{rpm}$ for $10 \mathrm{~min}$. The supernatant $(0.2 \mathrm{ml})$ was made up to $10 \mathrm{ml}$ with distilled water. This solution was diluted 10 fold. Sample solution $(5 \mathrm{ml})$ was mixed with saturated sodium carbonate $(0.5 \mathrm{ml})$ and Folin-Ciocalteaue reagent $(0.2 \mathrm{ml})$ and made up to $10 \mathrm{ml}$ with distilled water. The absorbance was read at $765 \mathrm{~nm}$ after $60 \mathrm{~min}$ by UV visible double beam spectrophotometer (Model Evolution 600, Thermo Electron, US).

\section{Determination of antioxidant activity}

Free radical scavenging activity of extracts was measured by the slightly modified method of [22]. The antioxidant capacity of the extracts was studied through the evaluation of the free radicalscavenging effect on the 1, 1-diphenyl-2-picrylhydrazyl (DPPH) radical. An aliquot $(100 \mu \mathrm{l})$ of fruit extract was mixed with $3.9 \mathrm{ml}$ of 0.1 mM DPPH methanolic solution. The mixture was thoroughly vortexmixed and kept in the dark for $30 \mathrm{~min}$. The absorbance was measured later, at $515 \mathrm{~nm}$, against a blank of methanol without DPPH. Results were expressed as percentage of inhibition of the DPPH radical.

Storage studies: RTS beverages were subjected to storage studies at room temperature for a period of 3 months by drawing samples at bimonthly intervals to evaluate changes in chemical and organoleptic parameters. The products were also evaluated for sensory qualities viz., colour, flavour, taste and overall acceptability by a panel of 10 judges using a 9-point Hedonic scale where, score 1 is for 'dislike extremely' and 9 for 'like extremely' [23].

\section{Statistical analysis}

The data obtained were analyzed statistically for analysis of variance (ANOVA) using using SPSS to evaluate the significance at $\mathrm{p}<0.05$.

\section{Result and Discussion}

The fruits of Chakiya variety were used to prepare the processed products. The chemical compositions of the fruit were given in table 
1. The total polyphenols, vitamin $\mathrm{c}$ and antioxidant activity in terms of DPPH \% scavenging activity was compared with the amla were given in table 2. The table 2 showed that amla candy, amla bar and toffee had $324 \mathrm{mg} / 100 \mathrm{gm}, 229 \mathrm{mg} / 100 \mathrm{gm}$ and $170 \mathrm{mg} / 100 \mathrm{gm}$ respectively vitamin $\mathrm{c}$ content. The total poly phenols content in candy, bar and toffee were found to be $11.34 \mathrm{gm} / 100 \mathrm{gm}, 6.56 \mathrm{gm} / 100 \mathrm{gm}$ and 4.33 $\mathrm{gm} / 100 \mathrm{gm}$ respectively. The DPPH \% scavenging activity was found maximum in candy followed by bar and minimum in toffee (Table 2). The maximum retention of vitamin c, polyphenol and antioxidant activity in candy is may be due to its processing, candy preparation does not have heating step of amla flakes, it requires steeping of flakes while toffee and bar requires frying of pulp and due to heat treatment, bioactive components in them are lower than the candy. The decrease in DPPH \% scavenging activity during heat processing of bar, candy and toffee is directly correlated with of total poly phenols content [22]. The optimized products were evaluated for sensory evaluation on 9 point hedonic rating for consumer acceptance; the data was given in (Table 3) shows that candy score highest overall acceptability of 8.51 followed by toffee with overall acceptability of 7.91 then amla bar having overall acceptability of 7.31 (Table 3). The highest value of overall acceptability for candy may be due to it sweet and sour taste which can easily be related to its high vitamin $\mathrm{c}$ content which aids to its sourness. The bioactive components when compare to fresh amla shows that value added products which retain bioactive components even after processing.

\section{Conclusion}

The Amla fruit, because of its high acidity and astringent taste, is not palatable for direct consumption; hence it is consumed mainly in processed form. It was found that amla can be utilized for the

\begin{tabular}{|c|c|}
\hline Characteristic & Results \\
\hline Moisture (\%) & 80.20 \\
\hline Protein (\%) & 01.50 \\
\hline Fat (\%) & 0.1 \\
\hline Vitamin C $\mathrm{mg} / \mathbf{1 0 0 g m}$ & 680 \\
\hline TSS ( ${ }^{\circ}$ B) & 8.12 \\
\hline Carbohydrates (\%) & 14.1 \\
\hline Acidity (\%) & 3.28 \\
\hline
\end{tabular}

Table 1: Chemical Composition of Amla

\begin{tabular}{|c|l|c|c|c|c|}
\hline S.No & Particulars & Amla & Candy & Bar & Toffee \\
\hline 1 & $\begin{array}{l}\text { Vitamin C } \\
(\mathrm{mg} / 100 \mathrm{gm})\end{array}$ & $680+6.93$ & $324+2.31$ & $229+1.61$ & $170+3.41$ \\
\hline 2 & $\begin{array}{l}\text { Total polyphenols } \\
\text { gm/100gm gallic acid } \\
\text { equivalent }\end{array}$ & $24.5+1.11$ & $11.34+4.37$ & $6.56+5.22$ & $4.33+1.66$ \\
\hline 3 & $\begin{array}{l}\text { DPPH \% scavenging } \\
\text { activity }\end{array}$ & 83.24 & 42.77 & 23 & 18 \\
\hline
\end{tabular}

Table 2: Effect of different processing treatment on the bioactive components of amla and its products.

\begin{tabular}{|l|l|c|c|c|c|}
\hline Sample & $\begin{array}{l}\text { Color \& } \\
\text { Appearance }\end{array}$ & Texture & Taste & Flavor & $\begin{array}{c}\text { Overall } \\
\text { acceptability }\end{array}$ \\
\hline Amla bar & 7.21 & 7.35 & 7.41 & 7.50 & 7.31 \\
\hline Amla toffee & 7.62 & 8.24 & 8.05 & 7.92 & 7.91 \\
\hline Amla candy & 8.54 & 8.40 & 8.60 & 8.54 & 8.51 \\
\hline
\end{tabular}

Table 3: Sensory evaluation of processed products. development of various value added products which retains bioactive components even after processing. The sensory scores shows that the processed products are not only good source of antioxidant but also have consumer acceptance.

\section{References}

1. Dubois M, Gilles KA, Hamilton JK, Rebers PA, Smith F (1956) Colorimetric methods for determination of sugars and related substances. Anal Chem 28 350-356.

2. Rajeshkumar NV, Therese M, Kuttan R (2001) Emblica officinalis fruit afford protection against experimental gastric ulcers in rats. Pharm Biol 39: 375-380.

3. Shankar G (1969) Aonla for your daily requirement of vitamin C. Ind. Hortic 13: 9-15.

4. Soni SK, Bansal N, Soni R (2009) Standardization of conditions for fermentation and maturation of wine from Amla (Emblica officinalis Gaertn.). Nat Prod Rad 8: 436-444.

5. Paul DK, Shaha RK (2004) Nutrients, vitamins and minerals content in common citrus fruits in the northern region of Bangladesh. Pak J Biol Sci 7: 238-242.

6. Mishra P, Verma M, Mishra V, Mishra S, Rai GK (2011) Studies on development of ready to eat amla (Emblica officinalis) chutney and its preservation by using class one preservatives. Am J Food Technol 6: 244-252.

7. Mishra V, Puranik V, Singh V, Verma M, Yadav N, et al. (2012) Development of vitamin $\mathrm{C}$ rich value added beverage. Am J Food Technol 7: 222-229.

8. Jamwal KS, Sharma IP, Chopra L (1959) Pharmacological investigation on the fruits of Emblica officinalis Gaertn. J Sci Ind Res 18c: 180-181.

9. Jayshri S, Jolly Cl (1993) Phytochemaical antibacterial and pharmacologyica investigations on Monordica chiranlia and Emblica officinalis. Ind J Pharm Sci 1: $6-13$

10. Deka BC, Sethi V, Prasad R, Batra PK (2001) Application of mixtures methodology for beverages from mixed fruit juice/pulp. J Food Sci Technol 38 615-618.

11. Tripathi VK, Singh MB, Singh S (1988) Studies on comparative compositiona changes in different preserved products of Amla (Emblica officinalis Gaertn). Var Banarasi Indian Food Packer 42: 62-66.

12. Mishra V, Mishra P, Rai GK (2010) Process and product standardization for the development of amla bar. Beverage Food World 37: 58-60.

13. Rastogi RP, Mehrotra BN (1993) Compendium of Indian Medicinal Plants. Central Drug Research Institute, Publication Information Directorate India.

14. Rao TS, Kumari KK, Netaji B, Subhokta PK (1985) Ayurveda siddha J Res 6 : 213-224

15. Patel SS, Goyal RK (2012) Emblica officinalis Geart: A comprehensive review on phytochemistry, pharmacology and ethnomedicinal uses. Res J Med Plant 6: 6-16.

16. AOAC (1997) Officials Methods of Analysis of Association of Analytic Chemists. AOAC, Washington DC, USA.

17. AOAC (1990) Officials Methods of Analysis of Association of Analytic Chemists AOAC, Washington DC, USA

18. Rangana S (2000) Handbook of analysis and quality control for fruits and vegetable products. ( $\left.2^{\text {nd }} E d n\right)$, Tata McGraw-Hill Publishing Company Ltd India.

19. Indian Pharmacopoeia (1996) Ministry of Health and Family Welfare. Govt. of India, Controller of Publications, New Dehli 2: 100-111.

20. Jayprakash GK, Singh RP, Sakariah KK (2001) Antioxidant activity of grape seed extracts on peroxidation models In vitro. Food Chem 73: 285-290.

21. Alothman M, Bhat R, Karim AA (2009) Antioxidant capacity and phenolic content of selected tropical fruits from Malaysia, extracted with different solvents. Food Chem 115: 785-788.

22. Pangborn RM, Roessler EB (1965) Principles of Sensory Evaluation of Foods (2nd Edn), Academic Press, USA

23. Murray JM, Delahunty CM, Baxter IA (2001) Descriptive sensory analysis: past, present, future. Food Res Int 34: 461-471. 